\section{Kentsel Dönüşüm Sürecinde İdari Yargı Kararları: İptal ve Tam Yargı Dava Örnekleri}

Administrative Judicial Decisions on Urban Transformation: Examples of Cancellation and Full Jurisdiction

\section{Nematollah A. FANID ${ }^{1}$ Dilek KAVACIK ${ }^{2}$}

Strategic Public Management Journal Volume 4, Issue 7, pp. 27-43 2018 (1)

DOI: $10.25069 /$ spmj.435327 Received: 21.06.2018 Accepted: 03.07.2018 (C) The Author(s) 2018 For reprints and permissions: http://dergipark.gov.tr/spmj

\title{
$\ddot{O} z$
}

Kentlerde yaşanan nüfus artışı, göç, çarpık kentleşme gibi nedenlerden dolayı kent planlanması zorunlu hale gelmiştir. Bu aşamada yapılan kent planlarını uygulama aracı olarak kentsel dönüşüm projeleri karşımıza çıkmaktadır. Kentsel dönüşüm; belli başlı nedenlerden dolayı kenti yaşanılabilir hale getirmek amacıyla uygulanan değişim ve dönüşüm sürecidir. Çalışmanın amacl, kentsel dönüşüm kavramının hukuki alanda dayanaklarına değinilerek, kentsel dönüşüm sürecinin hukuki alt yapısını açıklamaktır. Bu kapsamda kentsel dönüşüm sürecinde gerçekleşen dava örneklerine yer verilmiştir. Kentsel dönüşüm kavramı, bir kent hareketi olduğu kadar bir hukuki boyutu da içinde barındırmaktadır. Kentsel dönüşüm kavramı, hukuki olarak değerlendirildiğinde belli başlı kanunlara dayanmaktadır. Kentsel dönüşüm süreci hukuki olarak dava türleri kapsamında iki şekilde ele alınabilmektedir. Kentsel dönüşüm sürecinde konu ve sebep bakımından farklılık gösteren sonuçlara baktığımızda iptal ve tam yargl şeklinde iki tür dava karşımıza çıkmaktadır. Bu dava türleri açısından kentsel dönüşüm sürecinde, yapılan dönüşüme ve plana bağlı olarak açılan davalar farklı şekilde sonuçlanabilmektedir. Günümüzde kentsel dönüşüm kapsamında açılan davalara bakıldığında birç̧ok örnek karşımıza çıkmaktadır. Kentsel dönüşüm sürecinde iptal davaları, yapılan projenin iptali gibi birçok sebeple açılmaktadır. Tam yargı davaları ise, az da olsa bu süreçte karşımıza çıkan dava türüdür. Çalışmada yöntem olarak literatür taraması yapılmış, bunun sonucunda örnek davalara yer verilmiştir.

Anahtar Kelimeler: Kent Planlama, Kentsel Dönüşüm, Dava Türleri, Yasal Dayanaklar

\section{Abstract}

Urban planning has become essential due to population increase, migration and uneven urbanization in cities. At this stage, urban transformation projects are arisen as a tool for implementing urban plans. Urban transformation is the process of change and transformation that is implemented in order to make the city viable for certain reasons. The purpose of the study is to explain the legal infrastructure of the urban transformation process by referring to the legal basis of the concept of urban transformation. In this context, examples of lawsuits that took place during the process of urban transformation are included. Although the concept of urban transformation is a city movement, it includes a legal dimension. When the concept of urban transformation is considered in legal context, it is based on certain laws. Urban transformation process can be considered in two types of lawsuits in legal perspective. When we look at the results that differ in terms of subject and reason during the process of urban transformation, two types

1 Dr. Ögr. Üyesi, Mehmet Akif Ersoy Üniversitesi, İktisadi ve İdari Bilimler Fakültesi, Kamu Yönetimi Bölümü, erdal.a.fanid@gmail.com

2 Mehmet Akif Ersoy Üniversitesi, Sosyal Bilimler Enstitüsü, Kamu Yönetimi Anabilim Dalı Yüksek Lisans Öğrencisi, dileekavack@gmal.com 
of lawsuits arise in the form of action of nullity and full remedy action. The lawsuits that are filed depending on the transformation and the plan can be concluded differently in the process of urban transformation. When we investigate the lawsuits filed today related to urban transformation, many examples can be seen. In the process of urban transformation, actions of nullity are filed for many reasons such as cancellation of the project. Full remedy actions are the kind of lawsuits that are seen less commonly within this process. In this study, literature review is done as the research method and sample lawsuits are given.

Key Words: Urban Planning, Urban Transformation, Types of Lawsuits, Legal Basis

\section{GíRiş}

Kentlerde; göç, yanlış yer seçimi tercihleri, ekonomik büyüme gibi etmenlerle meydana gelen nüfus artışına bağlı olarak mekânsal açıdan bir çöküntü yaşanmaktadır. Gelişen teknolojik hareketler ve yapısallaşmayla kentlerde planlı dönüşüm zorunlu hale gelmiştir. Kentsel dönüşüm, kentin oluşan yapısal sıkıntılardan arınması için bir çözüm yolu olmaktadır. Amaç bakımında da kentin yenilenmesini sağlayan bir olgudur.

Ülkemizde Kentsel Dönüşümün hukuki açıdan altyapısının oluşturulması bakımından oldukça yeni bir kentsel planlama süreci olduğu söylenebilmektedir. Bu çalışmanın amacı; kentsel dönüşüm kavramının tarihsel açıdan Dünya ve Türkiye örnekleri ele alınarak karşılaştırmalı şekilde açıklanacak ve hukuki bağlamda alt yapısına değinilecektir. Bu çalışma bağlamında kentsel dönüşüm sürecinde iptal davaları ve tam yargı davalarına örnekler verilerek açıklanacaktır. Çalışmanın kapsamı; kentsel dönüşüm çerçevesinde hukuki boyutlar değerlendirilerek iptal ve tam yargı davalarına örnekler verilerek açıklanacaktır. Çalışmada yöntem olarak; kütüphane ve alan çalışması yapılmıştır. Bunun yanı sıra hukuki alan için konu kapsamında dava örnekleri ve kararlarından yararlanılmıştır.

Çalışma 6 bölümden oluşmaktadır. Çalışmanın birinci bölümünde, çalışmaya giriş yapılarak çalışmanın kapsamı bakımından kısaca bir açıklama yapılmıştır. Çalışmanın ikinci bölümünde, kavramsal bir çerçeve oluşturularak, kent, kent planlama konuları kısaca açıklanarak kentsel dönüşüm kavramının alt yapısı oluşturulmaya çalışılmıştır. Bunların sonrasında kentsel dönüşüm kavramına girilerek amacı, yöntemleri ve somut bir bakış oluşturması için örnekler verilmiştir. Çalışmanın üçüncü bölümünde, kentsel dönüşüm kavramının ortaya çıkışı ve gelişimine değinilmiştir. Çalışmanın dördüncü bölümünde, kentsel dönüşüm sürecinin yasal dayanaklarına değinilerek, bu kapsamda yer alan ve alt yapı oluşturan kanunlar açıklanmıştır. Çalışmanın beşinci bölümünde, kentsel dönüşüm sürecinde karşılaşılan iptal ve tam yargı davalarına değinilmiştir. Bu kapsamda bu davaları detaylandırmak amacıyla örnek davalara yer verilmiştir. Çalışmanın altıncı bölümünde ise, sonuç kısmı yer almaktadır. Çalışmanın sonucunda ulaşılan bilgiler açıklanarak çıkarımlar yapılmıştır.

\section{KENTSEL DÖNÜŞÜMÜN AMACI VE ÖNEMI}

Kent, kapsam açısından bakıldığında birçok tanıma sahip olan ve tek bir tanıma sığdırılabilmesi oldukça zor bir kavramdır. Kent kavramının varlığından bahsedebilmek için toplumsal grupların yerleşik hayata geçmesi gerekir. Çünkü topluluk halinde bir yerleşim olmadır ki orada kent özellikleri ortaya çıksın. Bu açıdan baktığımızda farklı kent tanımlarından bahsetmek gerekir:

Ruşen Keleş'e göre kent, "Insanların hayatlarını devam ettirdikleri alan, toprak parçası" olarak tanımlanmaktadır (Keleş, 2004:73).

Kentler ve mekânlar, insanın hayatını devam ettirdiği alanlardır. Kentler, etrafındaki bölgelerin bir ürünüdür. Sosyal ve ekonomik ihtiyaçları devam ettirecek şekilde gelişmektedirler. (Çakallı, 2015:9).

Olcay İmamoğlu'nun kent tanımına göre, “Kent, birçok özellikleriyle kır tanımının tam tersi bir anlama gelmektedir. Kenti kırdan ayıran temel belirleyicilerin başında ise tarım dışı üretim, iş bölümü, nüfus 
yoğunluğu, kültür birikimi gelmektedir. Burada kültür birikimi ifadesiyle anlatılmak istenen, kentlere göç yoluyla gelen toplulukların farklı inanç, gelenek ve göreneklere sahip olmasına rağmen bir arada yaşaması ve bir topluluk oluşturmasıdır. Kent içinde yaşamanın en olumlu yanı sağlık ve kültür hizmetlerine kolayca ulaşabilmektir ve kent dışı yaşam ise daha fazla özgürlük, çevre kontrolü ve doğaya yakınlık sağlar." (İmamoğlu, 1995:357-367).

Kentleşme kavramı ise; kent olgusu ile birlikte ortaya çıkmış ve üzerinde birçok tartışmanın yaşandığı çok geniş kapsamlı bir konu olmuştur. Kentleşme, kent sayısının ve kentlerde yaşayan insan sayısının yükselmesi şeklinde tanımlanmaktadır. (Keleş, 1992:22).

Kent sayısının artması ve nitelikli bir gelişim anlamına gelen kentleşme, nüfusun tümü üzerinde pek çok etkide bulunmaktadır. Bu süreç nüfus çoğunluğunu kentlere çekmekle kalmamış, kırsal alanlara ve köy topluluklarına kadar yayılmıştır.

Kentler, bölgeleri içinde bir bütün mekân olarak, sosyal ve fiziksel verilerle ele alındığ 1 yaklaşımlarla planlanmaktadır. Kent planlama, 1970'lerden itibaren aynı tip planların yapılışı ile sürdürülmektedir. Aynı tip planlar birbirinin benzeri olan yani tek tipleşen kentleri yaratmışlardır (Erbey, 2004/4:79).

Kent planlama, gündemin en gözde konusu olan kentsel dönüşüm projeleri, planlama faktörlerinin uygulama aracı haline gelmektedir. Kentsel dönüşüm projeleri, kentte var olan kültürel yapı ve tarihi mirasın korunmasını amaçlayan bir araçtır (Erbey, 2004/4:80).

Tarihsel süreç içerisinde kentler, bazı dış faktör ve dinamiklerin etkisiyle sürekli dönüşüme uğramışlardır. $\mathrm{Bu}$ dönüşüm ve buna bağlı olarak yaşanan değişim süreci, 19. Yüzyılda başlayan sanayileşme ve beraberinde getirdiği diğer gelişmeler ile birlikte hızlanmış, dahası bu değişim ve dönüşüm olgusu, o güne kadar kentlerin tecrübe etmediği mekânsal, toplumsal ve hatta ekolojik sorunları da beraberinde getirmiştir (Çakalli, 2015:17).

Kentsel dönüşüm, bozulmanın yaşandığı kentsel alanın toplumsal ve çevresel koşullarını çeşitli yaklaşımlarla iyileştirmeye yönelik uygulanan eylemlerin tümüdür (Akkar, 2006:29). Kentsel dönüşüm süreci, yapısal açıdan yaşanılabilirligini kaybetmiş, artık faydalı kullanımın sağlanamadığ elverişsiz alanların tekrar kazandırılması amacıyla kullanılan bir süreçtir.

Farklı tanıma bakacak olursak, Özden'e göre kentsel dönüşüm; “Farklı nedenlerden ötürü zaman süreci içinde eskimiş, köhnemiş, yıpranmış ya da kimi durumlarda terk edilmiş, vazgeçilmiş kentsel dokunun, günün sosyo-ekonomik ve fiziksel koşullarl göz önünde tutularak değiştirilmesi, dönüştürülmesi, ıslah edilmesi ve yeniden canlandırllarak kente kazandırılmasıdır." şeklinde ifade edilebilir (Özden, 2001:23).

Kentsel dönüşüm kavramı yere, zamana ve kişilere göre farklılıklar gösteren bir kavram olduğundan, kavram ile ilgili olarak zaman içerisinde farklı anlamlar, tanımlamalar yapılmış, yine yeni anlamlar, tanımlamalar yüklenmiş ve sonuçta bu kavram ile ilgili sınıflandırma biçimleri ortaya çıkmıştır (Özer, 2006:25).

Kentsel dönüşümün mekânsal ve fiziki boyutu var olmakla birlikte, uygulamada sadece fiziki olarak mekânın dönüştürülmesi olarak hayata geçirilmiş, en az mekânsal dönüşüm kadar önemli olan toplumsal ve ekonomik boyutları göz ardı edilmiştir. Oysaki kentsel dönüşüm sadece mekânların dönüştürülmesinden ibaret olmayıp, çöküntüye uğramış veya bozulmuş olan mekânın yeniden biçimlendirilmesinin yanında kentte potansiyel olarak bulunan sosyal ve ekonomik dinamikleri etkileyerek bu yolla bahsedilen çöküntüye uğramış kentsel alanların kente yeniden kazandırılmasını sağlayan uygulamaları ifade etmektedir. Yani sosyal ve ekonomik dinamiklerle kast edilen kentin gelişmesiyle denk ölçüde gelişen sosyal alanlar üniversiteler, hastaneler gibi alanlardır (Çakallı, 2015:22-23).

Kentsel dönüşümün amacı kent için önemli olan, ancak çeşitli nedenlerle zarara uğramış, eskimiş ya da bu süreçlerin henüz yaşamakta olduğu kent parçalarının kullanılır hale getirilmesidir (Özden, 2008:45). 
Çöküntüye uğramış alanlarda yaşayan insanların kentin diğer bölgelerine göre nispeten altyapı gibi kentsel imkânlardan daha az faydalanması veya bazı imkânlardan hiç faydalanmaması, çöküntüyü yaşayan bu insanların bir sosyal dışlanma yaşamalarına sebep olabilmektedir. Kentsel dönüşüm sosyal dışlanmanın azaltılmasını amaçlamakla sosyal barışa da katkıda bulunabilmektedir (Çakallı, 2015:24).

Kentsel dönüşüm kavramı, özellikle 1980'li yıllardan itibaren kentleşmenin hızlanmasıyla kent merkezlerine akın eden nüfusu, yıpranmış kentsel dokuyu yeniden kente kazandırarak bu bölümlere yönlendirmek amacıyla sıkça gündeme gelmeye başlamıştır. (İnce, 2006:21).

Kentsel dönüşümün aşağıda belirtilen beş önemli amacı vardır (Akkar, 2006:30):

-Kentin mekânsal şartları ile sosyal sorunları arasında ilişki kurulması,

-Kent yapısını meydana getiren çok fazla öğenin toplumsal olarak durmadan değişim ihtiyacını karşılamak,

-Kentin yaşam kalitesini geliştirici başarılı bir kalkınmayı sergilemek,

-Kentsel alanların etkin şekilde kullanımını önlemek amacıyla tedbirlerin konulması,

-Toplumsal koşullar olarak kentsel politikanın geliştirme ihtiyacını karşılamayı amaçlamaktadır.

Her kentin fiziksel, toplumsal ve ekonomik özellikleri birbirinden farklı olduğundan, kentsel dönüşüm projelerinin hazırlanmasında ve uygulanmasında bu farklılığın gözetilmesi şarttır. Başka bir deyişle her kent kendine özgü ayırt edici bazı özellikler gösterir. Bunun ötesinde aynı kent içerisinde bile bazen farklı özelliklere sahip olan fiziksel mekanların bulunması son derece doğal olup, bir kentsel mekan için hazırlanan kentsel dönüşüm projesinin aynen başka bir kentsel mekanda uygulanması her zaman mümkün olamamakta, uygulamada sorunlarla karşıllaş1labilmektedir (Çakallı, 2015:27).

Dünya çapında kentsel dönüşüme baktığımızda amacı; yenidünya aşamasında kentlerin rekabet şartlarını geliştirmek, yurtdışı firmalarını yöneltmek, ulusal sisteme adaptasyonu arttırmak yani "Evrensel Dünya Kenti” olmaktır (Bayram, 2006:11).

\section{KENTSEL DÖNÜŞÜMÜN ORTAYA ÇIKIŞI VE GELIŞİII}

Dünya'da kentsel dönüşüm süreçlerini üç ana evrede incelemek mümkündür. Bu üç ana evre, kentleşmenin alt yapısının oluştuğu süreçtir. İlk evre hareketinin 19. Yüzyılda yaşandığı ve devam ettiği görülmektedir. 19. Yüzyılda sanayi kapitalizmi, ekonomik ve toplumsal değişimi birlikte getirmiştir. Bu dönem dünyada sanayileşme, kentleşme ve modernleşme sürecidir. İkinci evre, 2. Dünya Savaşı sonrasında Avrupa'nın tekrar yapılanma esnasında yaşanmıştır. Bu dönüşümün üçüncü evresi ise, 1970'lerden itibaren yaşanan krizle beraber bütün dünyada üretimin değiştiği bir dönemidir (Aşık, 2007:27).

Kentsel dönüşümün ilk örneği, sanayileşen Avrupa'da yeniden inşa tarzında gelişen yenilemedir. Bu dönemde, İngiltere'de konut politikasını geliştirmek amacıyla Konut Kanunu çıkarılmıştır. Bu dönemde bahsedilmesi gereken diğer önemli bir süreç ise, 1851'den 1870'e kadar "Haussman Politikaları"dır (Çakallı, 2015:32).

Bu dönemde Fransa'da ise, "Temizleme Sonrası Modernizm” denilen tutum kabul edilmiştir. Bu tarihsel süreçte, Avrupa ve ABD'de uygulanan politikalar ve programlar karşılaştırıldığında büyük farklılıklar olduğu görülmektedir. Örneğin, İngiltere'de kentsel yenileme operasyonları, devlet kurumları tarafından yönetilmiş ve uygulanan programlar düşük standartlardaki konut alanlarında yaşayan kesimi, bu konutlardan çıkartarak yeni konut alanlarına yerleştirmiştir. Bunun tam tersine, ABD'de uygulanan birçok yenileme programını özel sektör kuruluşları yönetmiştir (İnce, 2006:30). Bu dönemde uygulanan projeler uygulanış biçimleri şeklinde farklılıklar göstermiş ve ihtiyaçlara cevap verebilecek projeler ortaya konmuştur. 
Türkiye'de yapılan kentsel dönüşüm çalışmalarına bakıldığında, İkinci Dünya savaşının sonrasında geliştirilen planlama çalışmaları, genel olarak kentin fiziksel düzenlemesiyle ilgilenmiştir. 1950'li yıllardaki genel planlama yaklaşımı; konum olarak merkez kabul edilen bölgelerin yıkılıp alt sınıf inşaların buradan çıkarılması ve bu alanlara yeni bir yaşam sunulması şeklindeydi. Bu dönem tarihte "Buldozer Dönemi” olarak geçmektedir. Ancak Buldozer Dönemi'ndeki uygulama eksiklikleri ve bunların toplum ve çevre üzerindeki olumsuz etkileri sebebiyle değişim ve yenileme sonrası modernizm ya da temizleme sonras1 modernizm dönemine geçilmiştir. 1950'lerdeki Buldozer Dönemi ile yenileme ve temizleme dönemlerinden sonra, 1960'larda bireyselliğe inanan toplumun buna dâhil olmasını talebe yönelik fikirler ortaya atılmaya başlanmıştır. 1970'li yıllar özellikle konut alanlarının iyileştirilmesi çalışmalarında büyük önem taşımaktadır. 1980'lere gelindiğinde, kentlerde daha çok çalışma alanı açmak için yenileme, kent merkezlerinde soylulaştırmanın ortaya çıktığı bir dönemdir. 1990'larda ekonominin gelişmesiyle başlayan büyüme amaçlı planlama çalışmalarında asıl amaç, mevcut durumda değişiklik yaratmayacak öneriler getirmektir. Uygulanabilirliği olan halkın beklenti ve ihtiyaçları karşılayacak projeler yapılmaya başlanmıştır (Akova, 2010:11-12).

Türkiye'de planlı döneme 1961 Anayasası döneminde geçilmiş ve 1963 yılında ilk defa bölge düzeyinde bölgesel kalkınma planları hazırlanmıştır. Tarihsel bağlamda dünyada çeşitli uygulamaları bulunan kentsel dönüşüm, Türkiye'de ilk defa 1980'li yıllarda konuşulmaya başlanmıştır. Fakat kentsel dönüşümün yaygın olarak kullanımı fazla eski değildir.

Kentsel dönüşüm ile ilgili düzenlemeler, 1848 Ebniye Nizamnamesi, sonra 1882 Ebniye Kanunu'nda yer almaktayken, Cumhuriyet Döneminde planlamaya yönelik düzenlemeler 1925 tarihinde yürürlüğe konulan 583 sayılı Kanun'da yer verilmiştir. 583 sayılı Kanun ile Ankara'nın geliştirilmesi, Başkent olarak planlanması amaçlanmıştır. Bu amaçla 1915 yılı değerlerinin 15 kat kadar üzerinde kamulaştırılma yetkisi verilmiştir. Bu sürecin sonucunda kent planlaması, 1928 tarihli ve 1351 sayılı, Ankara Şehri İmar Müdürlüğü Teşkilat ve Vazifelerine Dair Kanun hükümlerini yer almıştır (Çakallı, 2015:42).

1966 tarihli 775 sayılı Gecekondu Kanunu Türkiye'de gecekondu bölgelerinin şartlarının düzeltilmesi, oluşan gecekondu bölgelerinin kaldırılması ve tekrar yapılması planlanan gecekonduları önlemek amacıyla yürürlüğe konulmuştur. 1970'li yıllar için Türkiye'de kentsel dönüşümün fikri alt yapısının hazırlandığı bir dönem olduğu söylenebilir.

Türkiye'de son zamanlarda, kentsel dönüşüm projelerini uygulamak yerel yönetimlerden beklenen bir durum haline gelmiştir. Bunun sonucunda uygulanan kentsel dönüşüm projelerinin birçoğunu yerel yönetimlerin yaptığı görülmektedir. Bu tür projelerin çok maliyetli olması ve kentsel dönüşüme özgü bir mevzuatın olmaması yerel yönetimlerin işlerini zorlaştırmaktadır (Çakallı, 2015:48).

Türkiye'de uygulanan kentsel dönüşüm projelerinin diğer bir olumsuz tarafina bakmak gerekirse; bu projeler parsel bazında ve parçacı şekilde yapılmaktadır yani bütüncül değildir. Bu şekilde parçalı bir şekilde olmasının nedenini bu süreci yerel yönetimlerin götürmesine bağlamak doğru olacaktır.

İkinci Dünya Savaşı sonrası tarihsel süreç dikkatle incelendiğinde, Türkiye'de kentlerin 50 yılı aşkın süredir sürekli dönüşüm içerisinde olduğu görülecektir. Ancak esas sorun, bu sürecin dışarıdan müdahaleler ile değil, kendiliğinden işleyen bir süreç olmasıdır. Bu sürecin doğal olarak sonucu olarak, Türkiye'de uygulamaya konulan dönüşüm projeleri, kentlerin tarihsel, çevresel, ekonomik ve sosyo-kültürel kimlikleri ile tutarlı olmaktan uzak kalmışlardır (Aşık, 2007:70).

Kentsel dönüşüm, var olan kent yapısının oluşturulması ve yenilenmesi için yapılan uygulamaları içinde barındıran bir süreçtir. Kentsel dönüşüm yöntemlerini beş başlık altında toplamak mümkündür. Bunlar; yenileme, eski haline getirme, yeniden canlanma, yeniden oluşum ve soylulaştırmadır (Çakallı, 2015:7787).

Yenileme; kamu yardımıyla yoksun çevrenin yenilenmesi, yapıların iyileştirilmesi ve daha iyi koşulların 
sağlanması şeklinde tanımlanabilir (Keleş, 1998:120).

Sağlıklaştırma olarak anılan eski haline getirme yöntemi; eskimiş, altyapısı ihtiyaçlara cevap vermeyecek duruma gelmiş kentsel mekânın yeterli hale getirilmesine yönelik çabaları ifade etmektedir. Eskimiş kent yapısını ve köhne alanların kullanıma açılması şeklinde ifade edilmektedir (Şahin, 2003:93).

Diğer bir yöntem olarak yeniden canlanma yöntemi; sözcük anlamı olarak, taze hayat bulma, kendine gelme anlamına gelmektedir. Sosyal ya da fiziksel açılardan bir yıpranmışlık süreci yaşanan alanlarda, bu çöküntüye sebep olan faktörlerinin ortadan kaldırılması ve giderilmesi anlamına gelmektedir (Çakallı, 2015:80-81).

Yeniden oluşum yöntemi; kentsel dönüşüm literatüründe, yeni bir kentsel doku oluşturma anlamında kullanılır. Refah seviyesi düşmüş yapıların tekrar kazandırılmasını amaçlayan bir yöntemdir (Şahin, 2003:94).

Soylulaştırma yöntemi ise; üst sınıf mekan sahiplerinin kentin bazı alanlarına yeniden yerleştirilmesini ifade eder. Bu aşamada mekânsal düzeltme ve iyileştirme önem arz etmektedir (Ertaş, 2011:5).

\section{KENTSEL DÖNÜŞÜMÜN YASAL DAYANAKLARI}

Kentsel dönüşüm kavramı, toplumsal ve kentsel açıdan var olan çarpıkların giderilmesi için sürdürülen bir dönüşüm sürecidir. Bu bağlamda bu sürecin işlerlik açısından verimli olabilmesi için hukuki alt yapısına değinmek gerekmektedir. Kentsel dönüşüm ve planlama, konu kapsamında var olan kanun ve düzenlemelerle devam ettirilebilir. Konu ile ilgili yasal düzenlemeleri şu şekilde sıralayabilir; 5226 sayılı Kültür ve Tabiat Varlıklarını Koruma Kanunu, 5216 sayılı Büyükşehir Belediyesi Kanunu, 2985 sayılı Toplu Konut Kanunu, 5302 sayılı İl Özel İdareleri Kanunu, Kentsel Dönüşüm ve Gelişim Kanun Tasarısi 5393 sayılı Belediye Kanunu, 5366 sayılı Yıpranan Kent Dokularının Yenilenerek Korunması ve Yaşatılarak Kullanılması Hakkında Kanun.

\subsection{Sayılı Toplu Konut Kanunu}

2985 sayılı Kanunla 1984 yılında yasalaşan Toplu Konut Kanunun 1. maddesine göre, "Konut ihtiyaçlarının karşılanması, konut inşaatını yapanların tabi olacă̆ı usul ve esasların düzenlenmesi, memleket şart ve malzemelerine uygun endüstriyel inşaat teknikleri ile araç ve gereçlerin geliştirilmesi ve devletin yapacağı desteklemeler bu kanun hükmüne tabidir." şeklinde ifade ederek kendi amaç ve kapsamını belirlemektedir. Buna ek olarak 6. madde ise TOKI'nin görevlerini açıklamaktadır. 6. maddeye göre; "TOKI, gecekondu bölgelerinin tasfiyesine veya iyileştirilerek yeniden kazanımıza yönelik olarak gecekondu dönüşüm projeleri geliştirilebilir, inşaat uygulamalart ve finansman düzenlemeleri yapabilir."

\subsection{Sayılı Büyükşehir Belediyesi Kanunu}

5216 sayılı Büyükşehir Belediyesi Kanunu'nun 3. maddesi Büyükșehir Belediyelerini tanımlamaktadır. İlgili Kanunun 3. maddesine göre, "Büyükşehir Belediyesi, en az üç ilçe veya ilk kademe belediyesini kapsayan, bu belediyeler arasında koordinasyonu sağlayan; kanunlarla verilen görev ve sorumlulukları yerine getiren, yetkileri kullanan; idari ve mali özerkliğe sahip ve karar organı seçmenler tarafindan seçilerek oluşturulan kamu tüzel kişisidir.”.

\subsection{Sayılı Kültür ve Tabiat Varlıklarını Koruma Kanunu}

5226 sayılı Kültür ve Tabiat Varlıklarını Koruma Kanunun son değişikliklerini de dikkate alarak ilgili Kanunun amacı "Korunması gerekli taşınır ve taşınmaz kültür ve tabiat varlıkları ile ilgili tanımları

${ }^{3}$ 01.03.2005 tarihinde TBMM gündemine girmiştir. Daha sonra almış olduğu tepkiler üzerine "Yıpranan Kent Dokularının Yenilenerek Korunması ve Yaşatılarak Kullanılması Hakkında Kanun” olarak değiştirilmiştir. (Resmi gazete tarihi: 05.07.2005) 
belirlemek, yapılacak işlem ve faaliyetleri düzenlemek, bu konuda gerekli ilke ve uygulama kararlarını alacak teşkilatın kuruluş ve görevlerini tespit etmektir." şeklinde tanımlanmaktadır (5226, md.1).

Kültür ve tabiat varlıklarının korunması ile ilgili 1982 Anayasanın sosyal ve ekonomik haklar ve ödevler bölümünde de yer verilmiştir. 63. Maddeye göre, "Devlet, tarih, kültür ve tabiat varliklarının ve değerlerinin korunmasını să̆lar, bu amaçla destekleyici ve teşvik edici tedbirleri alır. Bu varlıklar ve değerlerden özel mülkiyet konusu olanlara getirilecek sinırlamalar ve bu nedenle hak sahiplerine yapılacak yardımlar ve tanınacak muafiyetler kanunla düzenlenir." (Anayasa, md.63).

Kültür ve tabiat varlıklarını korunması amacıyla 5226 sayılı Kanunun 51. maddesine istinaden, Kültür Varlıklarını Koruma Yüksek Kurulunun görev ve yetkilerini görebiliriz. 51. Maddeye göre, bu görevler; "Korunması gerekli taşınmaz kültür ve tabiat varlıklarının korunması ve restorasyonuyla ilgili işlerde uygulanacak ilkeleri belirlemek, koruma kurulları arasında gerekli bir koordinasyonu sağlamak, uygulamada doğan genel sorunları değerlendirerek görüş vermek suretiyle, Bakanlığa yardımcı olmaktır."

5366 sayılı Kanunun 2. Maddesine istinaden Kültür ve Tabiat Varlıklarını Koruma Kanunuyla görev, yetkileri öngörülen Koruma Yüksek ve Koruma Bölge Kurulları, istinaden, Yenileme alanlarında görevlendirilmişlerdir. Yenileme alanlarında hazırlanacak Avan projeler 5366 sayılı Kanun uyarınca oluşturulacak kurullar tarafindan onaylanmak zorundadır (Yılmaz, 2009:36).

\subsection{Sayılı İl Özel İdareleri Kanunu}

İl Özel İdareleri Kanunu'nun 3. maddesi il özel idaresi şu şekilde tanımlamaktadır; "İl halkının yerel ortak nitelikteki ihtiyaçlarını karşılamak üzere kurulan ve karar organı (il genel meclisi) seçmenler tarafindan seçilerek oluşturulan, mali ve idari özerkliğe sahip kamu tüzel kişisidir."

İl özel idareleri her ne kadar büyükşehirlerde kaldırılsa da yene de bu kuruluşlar, sadece merkezden yönetime bağlı başkent teşkilatı yönetiminin sembolik temsilcisi değildir. Bu kuruluşlar belediyeler kadar olmasa da yene de aktif şekilde çalışan; kente toplumsal hatta ekonomik müdahale kararlarını alan ve bu kararları uygulayan önemli bir idari birim olması gerekmektedir (Yılmaz, 2009:38).

\subsection{Sayılı Yıpranan Kent Dokularının Yenilenerek Korunması ve Yaşatılarak Kullanılması Hakkında Kanun}

5366 sayılı Kanunun 1. maddesi uyarınca, bu Kanunun amac1, "büyükşehir belediyeleri, il, ilçe belediyeleri ve nüfusu 50.000 'in üzerindeki belediyelerce ve bu belediyelerin görev ve yetki alanı dışındaki il özel idarelerince, özelliğini kaybetmeye yüz tutmuş ve yıpranan, kültür ve tabiat varlıkların koruma kurullarınca sit alanı olarak tescil ve ilan edilen bölgeler ile bu bölgelere ait koruma alanlarının, bölgenin gelişimine uygun olarak yeniden inşa ve restore edilerek, bu bölgelerde konut, ticaret, kültür, turizm ve sosyal donatı alanları oluşturulması, tabii afet risklerine karşı tedbirler alınması, tarih ve kültürel taşınmaz varlıkların yenilenerek korunması ve yaşatılarak kullanılmasıdır.",

Ayrıca 5366 sayılı Kanunun uygulamasına dair Yönetmeliğin 8. maddesi uyarınca; "Yetkili idare öncelikle yenileme uygulaması yapacağı bölgeyi tespit ederek halihazır harita üzerinde koordinatlı olarak yenileme alanı sınırlarını belirler. Belirlenen yenileme alanında tüm çalışmaları yapmak üzere uygulama birimini görevlendirir. Yenileme alanının tespitinde, tarihi ve kültürel özellikler ile afet riskleri dikkate alınır." hükmü yer almaktadır.

"8. maddeye istinaden, koruma alanının belli tarihi özelliklerini kaybetmeye başlamış alanlar olması sebebi ile yenileme alanı ilan edileceğinin, uygulama yönetmeliğinde de ayrıntılı bir biçimde anlatılması önemlidir." (Y1lmaz, 2009:45).

\subsection{Sayılı Belediye Kanunu}

1984 tarihinde yürürlüğe giren Belediye Kanunu, 2005 tarihinde esaslı bir biçimde değişikliğe uğramıştır. 
Belediye Kanunun 3. maddesi, belediye, belediye organları, belde ve mahalle kavramlarını tanımlamıştır. Belediye bu Kanunun 3. maddesi uyarınca; "Belde sakinlerinin yerel ortak nitelikteki ihtiyaçlarını karşılamak üzere kurulan ve karar organı seçmenler tarafindan seçilerek oluşturulan, idari ve mali özerkliğe sahip kamu tüzel kişisi” olarak açıklanmıştır. Bu madde bize şunu vurgulamaktadır; belediyelerin asli görevi, kendi sınırları içinde ikamet eden sakinlerin ayrıca kurum ve kuruluşların ortak ihtiyaçlarını karşılamaktır.

Belediye Kanunu'nda, kentsel dönüşüme dair ilke ve kurallar sadece "Kentsel dönüşüm ve gelişim alanları" başlı̆̆ 1 altında 73. maddede düzenlemiştir. 73. maddeye göre; "Belediye, belediye meclisi kararıyla; konut alanları, sanayi alanları, ticaret alanları, teknoloji parkları, kamu hizmeti alanlarl, rekreasyon alanları ve her türlü sosyal donatı alanları oluşturmak, kentin gelişimine uygun olarak eskiyen kent kısımlarını yeniden inşa ve restore etmek; konut alanlart, sanayi ve ticaret alanlart, teknoloji parklart ve sosyal donatılar oluşturmak, deprem riskine karşı tedbirler almak veya kentin tarihi ve kültürel dokusunu korumak amacıyla kentsel dönüşüm ve gelişim projeleri uygulayabilir. Bir alanın kentsel dönüşüm ve gelişim alanı olarak ilan edilebilmesi için yukarıda sayılan hususlardan birinin veya bir kaçının gerçekleşmesi ve bu alanın belediye veya mücavir alan sınırları içerisinde bulunması şarttır. Ancak, kamunun mülkiyetinde veya kullanımında olan yerlerde kentsel dönüşüm ve gelişim proje alanı ilan edilebilmesi ve uygulama yapılabilmesi için ilgili belediyenin talebi ve Çevre ve Şehircilik Bakanliğının teklifi üzerine Bakanlar Kurulunca bu yönde karar alınması şarttır."

\section{KENTSEL DÖNÜŞÜM SÜRECINDE IDARİ DAVA TÜRLERİ}

İptal ve tam yargı davaları, idari yargılama hukukunun önemli iki davasıdır. İdari yargı davaları, 2577 sayılı İdari Yargılama Usulü Kanunu'nun 2. maddesinde düzenlenmiştir. Bu dava türleri;

1-İdari işlemler hakkında yetki, şekil, sebep, konu ve maksat yönlerinden biri ile hukuka aykırı olduklarından dolayı iptalleri için menfaatleri ihlal edilenler tarafından açılan iptal davaları,

2-İdari eylem ve işlemlerden dolayı kişisel hakları doğrudan muhtel olanlar tarafından açılan tam yargı davaları,

3-Tahkim yolu öngörülen imtiyaz şartlaşma ve sözleşmelerinden doğan uyuşmazlıklar hariç, kamu hizmetlerinden birinin yürütülmesi için yapılan her türlü idari sözleşmelerden dolayı taraflar arasında çıkan uyuşmazlıklara ilişkin davalardır.

İdari Yargılama Usulü Kanunu'nun 2. maddesinin 2/a bendine göre; “Ídari yargl yetkisi, idari eylem ve işlemlerin hukuka uygunluğunun denetimi ile sınırlıdır. İdari mahkemeler; yerindelik denetimi yapamazlar, yürütme görevinin kanunlarda gösterilen şekil ve esaslara uygun olarak yerine getirilmesini klsitlayacak, idari eylem ve işlem niteliğinde veya idarenin takdir yetkisini kaldıracak biçimde yargı kararı veremezler".

\subsection{Kentsel Dönüşüm Sürecinde İptal Davaları}

İptal davaları, yargı sistemimizin alındığı Fransa'da, Fransız Danıştay’ı tarafından geliştirilmiştir. Fransız devrimi ile adalet mahkemelerinin yönetsel kararlara karşı açılacak davalara bakmaların yasak edilmiş olması, hukuka aykırı kararlara karşı yönetime başvurmaktan başka çare bırakmamıştı. Devlet başkanı yönetsel denetim yetkisini Danıştay'ın yardımı ile kullanılan yönetsel denetim, zamanla yargı denetimine dönüşmüştür. 1872 yılında çıkarılan bir yasa ile tutuk adalet yönetimine son verilerek yönetsel kararlara karşı açılacak iptal davalarına bakma görevi Danıştay’a verilmiştir (Gözübüyük, 1996:117).

Ülkemizde 1868 yılında Fransız örneğine göre kurulan Danıştay'da da “Tutuk adalet” yöntemi uygulanıyordu. Danıştay'ın tam bir yargı yeri durumuna gelmesi ve iptal davalarına bakabilmesi, Cumhuriyet Döneminde, 23 Kasım 1952 yılında çıkarılan 669 sayılı Şurayı Devlet Kanunu ile olmuştur. $\mathrm{Bu}$ tarihten sonra çıkarılan Danıştay yasalarında, iptal davaları yönünden değişiklik olmamıştır. 669 sayılı 
Kanun ile benimsenen ilkeler, 1965 yılında çıkarılan Danıştay Kanunu'nda ve 1982 yılında çıkarılan 2577 Sayılı İdari Yargılama Usulü Kanunu'nda esas itibariyle korunmuştur (Gözübüyük, 1996:117). Burada bahsedilen "Tutuk Adalet” kavramını açıklamakta yarar vardır. İdari yargılama hukukunda tutuk adalet anlayışı, birey haklarının etkili bir şekilde korunmasının önüne konulan engelleri ifade etmektedir.

İptal davalarının özellikleri aşağıdaki şekilde özetlenebilir (Mirzaoğlu, 2017:40):

-İptal davasının konusunu idari işlemler teşkil ederler. Yani eylemlerin değil işlemlerin iptali olmaktadır.

-İptal davaları, kesin ve yürütülmesi gereken idari işlemler hakkında açılabilir (IYYUK. m.14).

İptal davaları, hukuka aykırı olduğu iddia edilen idari işlemlere karşı açılır. Bu dava ile idari işlemlerin beş ana unsuru; maksat, konu, sebep, yetki ve şekil yönünden işlemin hukuka uygunluğu denetlenir (IYUK, md.2/1-a).

Iptal davasında göreve ilişkin koşullara bakmak gerekirse; iptal davasının görevsiz yargı yerinde açılmış olması halinde, açılmış olan dava idari yargı kolunun görev alanının dışında olduğuna karar verilirse, bu dava için görevsizlik kararı verilir. Açılan iptal davası, yanlış idari yargı yerinde açılmış ise görevsizlik kararı verilir. Bunun sonucunda görevsizlik kararını veren mahkeme dosyayı görevli olan idari yargı yerine gönderir (IYYUK, md.9/1-2).

İptal davasında yetkiye ilişkin ön koşullara gelindiğinde; idari yargıda yetki sorunu vergi mahkemeleri veya idare mahkemeleri arasında ortaya çıkabilmektedir. 2577 Sayılı İdari Yargılama Usul Kanunu'nun 15. maddesine göre idare mahkemesine açılmış olan davanın adli yargının görev alanına girmesi halinde idari yargı tarafından dava reddedilerek görevsizlik kararı verilir. Dava, idari yargı düzeninin görev alanına girmekle beraber, görevli ve yetkili olmayan mahkemede açılmış ise, dava görev ve yetki yönünden reddedilerek, yargı yeri tarafından dosya görevli ve yetkili idare mahkemesine gönderilir (IYUK, md.15).

Ítal davasında süreye ilişkin koşullara geldiğimizde ise; kanunların öngördüğü süreler içinde açılmalıdır. Süreler de görev ve yetki gibi kamu düzeni ile alakalıdır, mahkemece re'sen düzeltilir. Uygun sürede açılmayan davalar, ilk inceleme ve ön koşullar açısından işin içeriğine bakılmaksızın reddedilir. Dava açma süresi, Vergi Mahkemelerinde otuz gün, İdare mahkemelerinde ve Danıştay'da altmış gündür (İYUK, md.7/1).

Belirtilen süreler; idari uyuşmazlıklarda, yazılı bildirimin yapıldığı; vergi, resim ve harçlar ile benzeri mali yükümlülükler ve bunların zam ve cezalarından doğan uyuşmazlıklarında; tahakkuku tahsile bağlı olan vergilerde tahsilatın, tebliğ yapılan hallerde veya tebliğ yerine geçen işlemlerde tebliğin; tevkif yoluyla alınan vergilerde istihkak sahiplerine ödemenin; tescile bağlı vergilerde tescilin yapıldığı ve idarenin dava açması gereken konularda ise ilgili merci veya komisyonun kararının idareye geldiği tarihi izleyen günden başlar (IYYUK, md.7/2-a,b).

İtal davasının konusuna ilişkin koşullara bakıldı̆̆ında; iptal davası açısından bu davalara konu olabilmesi için birkaç şartın gerçekleşmesi gerekir. Bunlara bakıldığında; idari ve İcrai bir işlem olmalı, kesin ve yürütülmesi gereken bir işlem olması gerekmektedir. (IYYUK md.5).

İtal davasında davacıya ilişkin koşullara baktığımızda; iptal davalarında gerek dava açabilme yeteneği, gerekse davada taraf olma yeteneği yönünden kural olarak, genel kurallar uygulanır. Medeni hakları kullanma yeteneğine sahip kişiler, iptal davası açabilirler. Dava açma ehliyeti açısından da, mekânların belirlenmesiyle ilgili karar veya kentsel dönüşüm projeleri sebebiyle hakları ihlal edilen herhangi bir kişi dava açma hakkına sahiptir. Bu kapsamda, bu alanda ikamet eden, malik, kiracı, ayni hak sahipleri gibi işlemden dolayı çıarı olumsuz etkilenebilecek kişiler dava ehliyetine sahiptir (Yasin, 2005:134).

Íptal davasında davalıya ilişskin koşullara baktığımızda; İptal davalarında davalı, iptali istenen kararı almış olan idari mercidir. Dava konusu işlemi yapmış olan kişiler ya da kamu görevlisi hasım olarak gösterilemez. Açılan davalar ilk inceleme aşamasında husumet açısından incelemeye tabi tutulacaktır (IYUK, md.14/3- 
f). İdari Yargılama Usul Kanunun 15. maddesine göre, "Davanın hasım yanlış hasım gösterilerek veya hasım gösterilmeden açılması durumunda, dava dilekçesinin tespit edilkten sonra gerçek hasma tebliğ edilecektir." (IYUK, md.15/1-c).

İptal davasında son olarak biçime ilişkin koşullara bakıldığında; idari davalar Danıştay, Vergi Mahkemesi ve İdare Mahkemesi başkanlıklarına yönelik yazılmış imzalı dilekçelerle açılır. Bu dilekçelerde aşağıdaki hususlar yer almalıdır (IYUK md.3):

-Dilekçelerde mahkemeye hitap olmalı,

-Davanın dayandığı deliler, konusu ve sebep olmalı,

-İdari işlemin yazılı bildirim tarihi olmalı,

-Dava konusu kararın ve belgelerin orijinalleri veya örnekleri dava dilekçesinde olmalıdır.

Tüm idari işlemler belirli biçim şartlarına uyarak tesis edilirler. İdari işlemin hukuki geçerlilik kazanabilmesi için yasa, tüzük yönetmelik gibi mevzuatta öngörülen biçim koşullarına uygun yapılması gerekir. İdari işlem yapılırken ön bir karar alınması veya bir görüş alınması gerekiyorsa, bu aşama atlanarak yapılan işlem hukuka aykırı hale gelir (Anayasa md.129).

Kentsel dönüşüm ile ilgili idari yargı alanlarında görülen davalara bakıldığında birçok örnek karşımıza çıkmaktadır. Konu kapsamında iptal sebebiyle açılan davalara örnek vermek mümkündür. Danıştay 6. Dairesinin 03.06.2009 gün E:2009/6171, K:2009/6621 sayılı kararında, "Dava, Mamak Belediyesince yapılan Hüseyin Gazi Mahallesi kentsel dönüşüm projesinin ve bu projeye bağh imar planı ve plan uygulamasının iptali istemiyle açılan dava karşımıza çıkmaktadır. 2575 sayılı Danıştay kanununun 24. Maddesinde belirtilen iptal davalarının Danıştay'da ilk derece mahkemesi olarak çözümleneceği, 2576 sayılı kanunun 5.Maddesinde de İdari mahkemelerinin, Danıştay'da çözümlenecek alanlar dışındaki davalara bakacă̆ı hükme bağlanmıştır. 2577 sayılı Yasanın 34. Maddesinde ise imar, kamulaştırma, yıkım, işgal, tahsis, ruhsat ve iskân gibi taşınmaz mallarla ilgili mevzuatın uygulanmasından veya bunlara bağlı her türlü haklara veya kamu mallarına ilişkin idari davalarda yetkili mahkemenin taşınmaz malların bulunduğu yerdeki idare mahkemesi olduğu belirtilmiştir. Dava konusu işlemlerin 2575 sayll Yasanın 24.Maddesinde belirlenen kapsamda tesis edilmiş bir işlem olarak kabul edilmesine olanak bulunmamaktadır. Bu durumda, kentsel dönüşüm projesi ve buna bağlı imar planı ve plan uygulamalarının iptali istemiyle açılan davanın çözümü, yukarıda anılan yasa hükümleri gereğince İdare Mahkemesinin görev alanı içinde bulunduğundan, Danıştay'da açılan davanın 2577 sayll Yasanın 15/1-a maddesi uyarınca görev yönünden reddine, dosyanın Ankara İdare Mahkemesi Başkanlığı'na gönderilmesine..." denilmek suretiyle dava dosyası yetkili ve görevli idare mahkemesine gönderilmiştir (Çakallı, 2015:145146).

Ankara 11. İdare Mahkemesi tarafindan verilen 25.01.2013 günlü, E:2012/1260, K:2013/140 sayılı kararın, usul ve hukuka aykırı olduğu beyan edilerek bozulması istemiyle yapılan temyiz incelenmesinde verilen Danıştay 6. Dairesinin 15.05.2014 tarih ve E:2013/3318, K:2014/3794 say1lı kararına göre, "Dava, Kuzey Ankara Girişi Kentsel Dönüşüm Projesi uygulama alanında arsaları ve ticari tesisleri bulunan davacı tarafindan, kentsel dönüşüme tabi tutulan taşınmaz maliklerine bir takım haklar veren 13.08.2010 tarihli Ankara Büyükşehir Belediye Meclis kararlarına dayanılarak, net metrekare kullanım alanlı işyerine karşıllk bu net metrekareyi karşılayacak şekilde işyeri verilmesi, bu işyerini kuraya dahil olmadan beğenerek seçmesi ve tesisine el koyulduğu Ekim 2007'den itibaren 6.000 TL kira bedeli ödenmesi istemiyle davalı idareye yaptığı başvurunun reddine ilişkin 29.06.2012 tarihli, 12812 sayll işlemin iptali talebiyle açılmış; İdare Mahkemesince, Kuzey Ankara Girişi Kentsel Dönüşüm Projesi kapsamında idarece kamulaştırma yapılmadan hak sahipleri ile karşıllklı rızaya dayalı olarak anlaşmaya varılarak sözleşme imzalandiğl, davacının taleplerine yine bu sözleşmeye dayalı bir hak talebi niteliğinde olduğu, dolayısıyla 
ortada karşıllklı irade beyanlarına dayandırılan sözleşmenin uygulanmasından kaynaklanan uyuşmazlık olduğu gerekçesiyle 2577 sayıl İdari Yargılama Usulü Yasasının 15/1-a maddesine hükmünce görev açısından reddine karar verilmiş ancak bu karar davacı vekili tarafindan temyize verilmiştir." (kararlar.uyusmazlik.gov.tr).

Danıştay 6. Dairesinin 15.05.2007 tarih ve E:2006/37, K:2007/2856 sayılı kararında, "Dava, Çankaya Belediye Meclisinin 08.03.2005 tarihli, 192 sayıl kararı ile uygun görülen Çankaya Mühye 902 Parsel Kentsel Dönüşüm ve Proje Alanını reddeden Ankara Büyükşehir Belediye Meclisinin 10.05.2005 tarihli, 1190 sayılı kararının iptali istemiyle açılmış; İdare Mahkemesince, dosyanın incelenmesinden dava konusu işlemlerin doğrudan doğruya davacı dernek tüzel kişiliğinin hak ve çıkarlarını ilgilendiren konularda iptal davası açabileceği, derneklerin tüzüklerinde belirttikleri her türlü konuya ilişkin olarak iptal davası açma olanağının kabul edilemeyeceği, dava konusu işlemlerin iptalini istemekte davacının hukuken korunması gereken bir menfaat iliş̧kisinin bulunmadiğının anlaşıldiğı gerekçesiyle davanın ehliyet yönünden reddine karar verilmiş; bu karar davacı vekili tarafindan temyiz edilmiştir. Davanın ehliyet yönünden reddi yolundaki temyize konu Ankara 2. Idare Mahkemesinin 05.10.2005 tarihli, E:2005/1376, K:2005/1411 sayılı kararında, 2577 sayılı kararında, 2577 sayılı İdari Yargılama Usulü Kanununun 49. Maddesinin 1. Fikrasında sayılan bozma nedenlerinden hiçbirisi bulunmadı̆̆ından, bozma istemi yerinde görülmeyerek anılan mahkeme kararının onanmasına, dosyanın adı geçen mahkemeye gönderilmesine” şeklinde ifade edilerek ilk derece mahkemesinin davanın ehliyet açısından reddine ilişkin kararı onanmıştır. (Çakallı, 2015:155).

\subsection{Kentsel Dönüşüm Sürecinde Tam Yargı Davaları}

İdari dava türlerinden bir diğeri, tam yargı davasıdır. Eski ifadeyle, "tam kaza” davası da adlandırılmaktadır. İhlal edilmiş bir hakkın yerine getirilmesi ya da uğranılan zararın giderilmesi istenir (Gözübüyük, 1996:229). Diğer bir ifadeyle tam yargı davası; idarenin, bir eylem ya da işlemi şeklinde ortaya çıkan davranışların sebep olduğu zararın giderilmesine ilişkindir.

Tam yargı davası deyimi, ilk kez 521 sayılı Danıştay Kanunu'nun 30. maddesinin (B) bendinde açıkça ifade edilmiştir. Bundan önceki yasada "tam yargı davaları" deyimi kullanılmamakla birlikte yasanın 23 . maddesinde yer alan "idari fiil ve kararlar yüzünden hakkı muhtel olanların açacakları davalar" şeklinde net olmayan bir biçimde tam yargı davalarından bahsedildiği kabul edilmiştir. Çünkü yasada yer alan bu kural ile davacı Danıştay'dan "ihlal” edilmiş olan hakkın geri verilmesini ya da uğradığı zararın giderilmesini isteme olanağına sahip olmuştur. (Danıştay Kanunu, md.30/b) Uygulamada da bu yönde gelişmiştir. 521 sayılı Danıştay Kanunu herhangi bir kuşkuya yer vermemek için açıkça tam yargı davasından söz etmiştir (Gözübüyük, 1996:229).

İlgililer menfaatlerini ihlal eden bir idari işlemden dolayı İdare Vergi Mahkemelerine ve Danıştay’a tam yargı davası açabilirler. Açılan dava sonucunda verilen karar neticesinde doğan zararlardan dolayı icra tarihinden itibaren dava süresi içinde tam yargı davası açabilirler (IYUK, md.12).

Tam yargı davaları, İdari Yargılama Usulü Kanunu'nun iptal davasına yer verilen maddeler kapsamında bulunmaktadır. Bu yüzden tam yargı davaları için ayrı bir madde açılarak anlatılmamıştır.

Tam yargı davalarının göreve ilişkin koşulları; İdare hukuku kapsamında tam yargı davalarında görevli yargı yeri idare mahkemeleridir. Genel şartlarda olduğu gibi görev yönünden yanlış mercilere açılan davalar görev yönünden ret edilir. Bu konuda sonradan açlacak olan davalarda idareye tekrar başvurma şartı aranmaz (IYUK, md.13/2).

Tam yargı davalarında konuya ilişkin koşullar; ön karar ve tam yargı davasının konusu olarak iki şekilde inceleyebiliriz. İptal davalarındaki gibi, koşul olarak tam yargı davalarında da bir ön karara ihtiyaç duyulmaktadır. İdari işlemler, idari sözleşmeler ve idari eylemler tam yargı davasının konusunu oluşturmaktadır. 
Tam yargı davalarında davacıya ilişkin koşullar; iptal davasında olduğu gibi bunda da genel kurallar uygulanır. Ancak tam yargı davası açabilmek için bir "hakkın ihlal" edilmiş olması gereklidir.

Tam yargı davasında davalıya ilişkin koşullar; davalı "idare” dir. İptal davasının tersine, tam yargı davaları tüzel kişiliği olan idareye açılır. İstisna olarak, idari sözleşmelerden doğan davalarda, gerçek kişiler veya özel tüzel kişileri de davalı olabilir. İlgililer haklarını ihlal eden bir idari işlem dolayısıyla Danıştay'a ve idare ve vergi mahkemelerine doğrudan doğruya tam yargı davası veya iptal ve tam yargı davalarını birlikte açabilecekleri gibi ilk önce iptal davası açarak bu davanın karara bağlanması üzerine, bu husustaki kararın veya kanun yollarına başvurulması halinde verilecek kararın tebliği veya bir işlemin icrası sebebiyle doğan zararlardan dolayı icra tarihinden itibaren dava süresi içinde tam yargı davası açabilirler. Bu halde de ilgililerin 11. madde uyarınca idareye başvurma hakları saklıdır (IYUK, md.12).

Tam yargı davalarında süreye ilişkin koşullar; tam yargı davasındaki sürelerin hukuksal niteliği, sürenin geçirilmesinin hükümleri iptal davasında olduğu gibidir. Özel kanunlarda farklı süre gösterilmeyen durumlarda İdare Mahkemeleri ve Danıştay'da 60 gün, Vergi Mahkemelerinde ise 30 gündür (IYYUK, md.7/1).

Tam yargı davalarında biçime ilişkin koşullar; tam yargı davaları dilekçe ile açılır. Dava dilekçeleri ya doğrudan doğruya davanın açıldığı yargı yerine ya da yasanın öngördüğü diğer yerlere verilir. Dilekçeler, Danıştay Daire Başkanı ve Vergi Mahkemesi Mahkeme Başkanı tarafından görevlendirilecek hakim ve üye tarafından görev ve yetki, ehliyet ve süre aşımı gibi konularda detaylı şekilde incelenmektedir (IYYUK, $\operatorname{md14/3)}$.

Bölge İdare Mahkemeleri, İdare Mahkemeleri, Danıştay ve Vergi Mahkemelerinde yargılama yazılı usulle yapılır. Yapılan işlemlerde inceleme ise kağıt üzerinden yapılır (IYYUK, md.1/2).

Tam yargı davalarını somut şekilde anlayabilmek için kentsel dönüşümle ilgili birkaç örnek vermekte fayda vardir:

Belediye Meclisi üyeleri tarafından açılan bir davada Danıştay 6.Dairesinin 24.07.2007 tarih ve E:2007/1342, K:2007/4697 sayılı kararında, "Dava Imrahor vadisi kentsel dönüşüm ve gelişim proje alanında sınır genişletilmesi ve etaplarına ilişkin 18.08.2006 tarihli, 2024 sayılı Ankara Büyükşehir Belediye Meclisi Kararının iptali istemiyle açılmış; Idare Mahkemesi tarafindan, dosyanın incelenmesinden, davacıların Ankara Büyükşehir Belediye Meclisi üyesi oldukları ve bu sıfatla dava açtıkları anlaşıldiğından, yasayla dava açma hakkı tanınmayan ve meclis üyesi sıfatı ile doğrudan menfaati ihlal edilmeyen davacıların salt dava konusu meclis kararı aleyhine oy kullanmış olmaları nedeniyle dava açmalarına olanak bulunmadiğı sebebiyle 2577 sayılı İdari Yargılama Usulü Kanunu'nun 15/1-b maddesine göre davanin ehliyet yönünden reddine karar verilmiştir. Bunun sonucundan bu karar davacılar tarafindan temyiz edilmiştir. Dosyanin incelenmesinden, davacılar tarafindan dava konusu imar planı değişikliğine iliş̧kin belediye meclisi kararına muhalif kaldıklarının iddia edildiği anlaşılmaktadır. Bu durumda İdare Mahkemesince, davacıların, dava konusu belediye meclisi kararının görüşüldügü toplantıya katılıp katılmadıkları veya katılıp karşı oy kullanmadıkları hususu açıklığa kavuşturulduktan sonra yeniden bir karar verilmesi gerekmektedir. Açıklanan nedenlerle, Ankara 2. İdare Mahkemesince verilen 01.11.2006 tarihli, E:2006/2364, K:2006/2186 sayll kararın bozulmasina, " denilerek eksik incelemeye dayalı kararın bozulmasina karar verilmiştir (Çakall, 2015:157-158).

İlk derece mahkemesi tarafindan verilen bir kararın temyiz incelemesinde, Danıştay, 6. Dairesinin 06.07.2010 tarih ve E:2010/396, K:2010/7248 sayılı kararında, “Dava, Ankara İli, Çankaya İlçesi, Dikmen Mevkii, Ilker Mahallesi, 158. Sokak No:32 adresinde tapu tahsis belgeli konut sahibi iken Dikmen Vadisi 4. ve 5. Etap Kentsel dönüşüm projesi kapsamında 17.02.2006 tarihli, 483 sayıl Ankara Büyükşehir Belediye Meclis kararı uyarınca davalı idare ile imzaladığ 10.08.2006 tarihli, 344 sayılı tapu tahsis belgesi tesis sözleşmesine göre; Dikmen Vadisi 4. Ve 5. Etap Kentsel dönüşüm projesi dâhilinde kalan 400 
metrekarelik tapu tahsisli konutun teslimi ve 72 ay 384.95 TL ödeme karşıllğında proje kapsaminda yaplacak konutlardan 100,00 metrekarelik bir konutun tarafina verilmesi, ayrica yeni yapilacak konut tarafina teslim edilinceye kadar 2006 yılı için 250.00 TL ve daha sonra artacak şekilde kira yardımı yapılması konusunda davalı idare ile anlaşan davacı tarafindan, idareye teslim ettiği ve idarece yıkılan konutu ve müştemilatı nedeniyle oluşan zararın gerekirse bilirkişi aracılığlyla hesaplattırllarak yıkım tarihinden ödeme tarihine kadar işleyecek yasal faizi ile birlikte tarafina tazminine ..." karar vermiştir (Çakallı, 2015:158).

Uyuşmazlık kapsamında ilk derece mahkemesinin temyiz aşamasında verilen Danıştay 6. Dairesinin 12.12.2011 tarih ve E:2011/8580, K:2011/5190 sayıl1 kararında, "İstemin Özeti: Davacı tarafindan, tapu tahsis belgesi arsası üzerinde oturduğu evin Dikmen Kentsel Dönüşüm Projesi kapsamında davalı idareyle yapılan sözleşme uyarınca ylkıldiğg ve sözleşme gereğince ev alma amacıyla 31 ay ödeme yaptı̆̆ından bahisle, evinin eski haline getirilmesini veya evinin ylkımından ve yapılan ödemelerden doğan $50.000 \mathrm{TL}$ maddi, 25.000 TL manevi tazminatın yasal faiziyle birlikte tarafina ödenilmesine karar verilmesi istemiyle açılan davanın görev yönünden reddi yolundaki Ankara 9. İdare Mahkemesinin 02.06.2011 tarihli, E:2010/1472, K:2011/1192 sayıl kararının usul ve hukuka aykırı olduğu ileri sürülerek bozulması istenilmektedir. (...) İdare ve vergi mahkemeleri tarafindan verilen karalarin temyiz yolu ile incelenerek bozulabilmeleri 2577 sayll İdari Yargılama Usulü Kanunu'nun 49.maddesinde belirtilen nedenlerden birinin bulunması halinde mümkündür. Ankara 9. İdare Mahkemesinin 02.06.2011 tarihli, E:2010/1472, K:2011/1192 sayll kararı ve dayandı̆̆ gerekçe, usul ve hukuka uygun olup, bozulmasını gerektirecek bir sebep bulunmadı̆̆ından temyiz isteminin reddi ile anılan kararın onanmasına, dosyanın adı geçen mahkemeye gönderilmesine" denilmiş ve mahkeme kararı onanmıştır (UYAP, Erişim tarihi:15.05.2018).

\subsection{Kentsel Dönüşüm Sürecinde İskân ve Kamulaştırma}

5543 sayılı İskân Kanunu'nun amac1; “Göçmenlerin, yaşadıkları yerler kamulaştırılanlar gibi menfaat kaybı yaşayanların haklarını düzenlemektir." şeklinde ifade edilmiştir (5543, md.1).

İskân Kanunu Ek Madde 1 gereğince; afet riski veya fen, sanat ve sağlık kurallarına aykırılık sebebiyle veya Bakanlar Kurulunca belirlenen özel proje alanlarında gerçekleştirilecek olan yeniden iskân uygulamalarında, buralardaki yerleşim merkezlerinde yaşayan ailelerin daha elverişli yerlerde iskânları ile köye dönüş projeleri çerçevesindeki iskân çalışmaları; ilgili proje için alınan Bakanlar Kurulu kararında belirtilen hak sahipliği ve borçlandırma usul ve esaslarına göre, Bakanlar kurulunca tespit edilen orman veya mera vasıflı alanlardan ve Hazinenin özel mülkiyetinde veya devletin hüküm ve tasarrufu altında bulunan taşınmazlardan uygun görülen yeni yerleşim yerlerinde, bu kanun hükümlerine göre yapılır.

644 sayılı Çevre ve Şehircilik Bakanlığının Teşkilat ve Görevleri Hakkında Kanun Hükmünde Kararname'nin 2. maddesinde, Çevre ve Şehircilik Bakanlığı; "Depreme karşı dayanıksız yapılar ile imar mevzuatına, plan, proje ve eklerine aykırı yapıların ve bunların bulunduğu alanların dönüşüm projelerini ve uygulamalarını yapmak veya yaptırmak" ifadeleriyle yetkilendirilmiştir. Bu genel bir yetkidir ve Çevre ve Şehircilik Bakanlığına kentsel dönüşüme istediği aşamada ve yerde müdahale etme ve istediği işleri bizzat yapma yetkisi vermektedir. Bakanlık adına bu yetki KHK'nın 11. maddesi ile Altyapı ve Kentsel Dönüşüm Hizmetleri Genel Müdürlügüne bırakılmıştır.

644 sayılı Çevre ve Şehircilik Bakanlığının Teşkilat ve Görevleri Hakkında Kanun Hükmünde Kararnamenin 11. maddesine göre; "Altyapı ve Kentsel Dönüşüm Hizmetleri Genel Müdürlüğü, dönüşüm, yenileme ve transfer alanlarının tespiti ile arsa ve arazi düzenleme ve değerleme iş ve işlemlerinin yapılmasın sağlamak; gerektiğinde acele kamulaştırma işlemlerini yürütmekle görevlendirilmiştir."

6306 Sayılı Afet Riski Altındaki Alanların Dönüştürülmesi Hakkında Kanunun Uygulama Yönetmeliği’nin 12. maddesinde kamulaştırma değer tespiti şu şekilde düzenlenmiştir:

-İlgili kurum, uygulama alanındaki taşınmazların sınırını, yüzölçümünü ve cinsini gösteren haritayı veya 
krokiyi yapar veya yaptırır ve bu taşınmazların maliklerini ve bunların adreslerini tespit eder veya ettirir.

-Taşınmazın değeri; ilgili kurum bünyesine en az üç kişiden teşkil olunacak kıymet takdir komisyonları marifetiyle veya hizmet satın alınmak suretiyle tespit edilir.

-Taşınmazın değeri; taşınmaz değerleme konusunda uzman kişi, kurum veya kuruluşlardan bilgi alınarak ve mahallin emlak alım satım bürolarından alınacak bilgilerden faydalanılarak, 04.11.1983 tarihli ve 2942 sayılı Kamulaştırma Kanunu'nun 11. maddesinde esaslara göre tespit edilir.

2942 Sayılı Kamulaştırma Kanunu'nun amaç ve kapsamı; “Kamu yararının gerektirdiği hallerde gerçek ve özel hukuk tüzelkişilerinin mülkiyetinde bulunan taşınmaz malların, Devlet ve kamu tüzelkişilerince kamulaştırılmasında yapılacak işlemleri, kamulaştırma bedelinin hesaplanmasını, taşınmaz malın ve irtifak hakkının idare adına tescilini, kullanılmayan taşınmaz malın geri alınmasını, idareler arasında taşınmaz malların devir işlemlerini, karşılıklı hak ve yükümlülükler ile bunlara dayalı uyuşmazlıkların çözüm usul ve yöntemlerini düzenler." şeklindedir (2942, md.1).

Kamulaştırma Kanunu'nun 10. maddesine göre kamulaştırma bedelinin mahkemece tespiti şu şekilde düzenlenmiştir:

-Kamulaştırmanın satın alma usulü ile yapılmaması halinde idare, 7. maddeye göre topladığı bilgi ve belgelerle 8. madde uyarınca yaptırmış olduğu bedel tespiti ve bu husustaki diğer bilgi ve belgeleri bir dilekçeye ekleyerek taşınmaz malın bulunduğu yer asliye hukuk mahkemesine müracaat eder ve taşınmaz malın kamulaştırma bedelinin tespitiyle, bu bedelin peşin veya kamulaştırma 3. maddenin 2. fikrasına göre yapılmış ise taksitle ödenmesi karşılığında, idare adına tesciline karar verilmesini ister.

-Mahkeme, idarenin başvuru tarihinden itibaren en geç 30 gün sonrası için belirlediği duruşma gününü, dava dilekçesi ve idare tarafından verilen belgelerin birer örneği eklenerek taşınmaz malın malikine meşruhatlı davetiye ile idarece yapılan araştırmalar sonucunda adresleri bulunamayanlara, 11.02.1959 tarihli ve 7201 sayılı Tebligat Kanunu'nun 28. maddesi gereğince ilan yoluyla tebligat suretiyle bildirerek duruşmaya katılmaya çağırır. Duruşma günü de idareye tebliğ olunur.

Kamulaştırma, Gecekondu Kanunu'nda geçici madde 5'de düzenlenmiştir. Düzenleme gereğince; “17 Ağustos ve 12 Kasım 1999 depremlerinde zarar gören Marmara Bölgesindeki illerde tabi afetler nedeni ile sağllkll, güvenli ve düzenli yeni yerleşim alanları oluşturmak ve konut ihtiyacını karşılamak amacıyla bedeli 15.05.1959 tarihli ve 7269 sayılı Kanunla teşkil olunan afetler fonundan sağlanarak kamulaştırılmış veya kamulaşttrllacak veya afetlere iliş̧kin hükümler taşıyan diğer kanunlara göre iktisap olunmuş veya olunacak arsa ve arazilerde, arsa ve konut üretimi için gerektiğinde 20.07.1966 tarihli ve 775 sayll Kanun hükümlerine göre işlem yapılır."

775 say1lı Gecekondu Kanunu'nun kamulaştırma ile ilgili olan 5. maddesine göre; "Lüzumu halinde, belediyeler gecekondu ıslah ve tasfiye sahaları içinde bulunan veya bu kanun hükümleri dairesinde yeniden teşkil edilecek önleme bölgeleri içine rastlayan özel mülkiyetteki arazi ve arsaları ve bunlar içerisinde yap veya herhangi bir tesis bulunduğu takdirde bu yapı ve tesisleri, bu kanunda belirtilen amaçlarda kullanmak üzere, Toplu Konut Idaresi Başkanlığının izni ile sahipleriyle anlaşarak satın alınabilir veya kamulaştırılabilir."

Kamulaştırma bedelinin artırılması ile ilgili Yargıtay 5.Hukuk Dairesinin 08.02.2007 tarih ve E:2006/14737, K:2007/1143 sayılı kararı aşağıdaki şekildedir:

“ÖZET: Dava kamulaştırma bedelinin arttırllması talebidir. Lüzumu halinde re'sen emsal celbi yoluna gidilmesi ve yeniden inceleme yapılıp gerekçeleri de belirtilmek suretiyle bilirkişi kurullarından ek rapor alınmadan yetersiz bilirkişi raporları esas alınarak hüküm kurulması isabetsizdir.

DAVA: Taraflar arasındaki kamulaştırma bedelinin artırılması davasının kısmen kabulüne dair verilen 
yukarıda gün ve sayıları yazılı hükmün Yargıtay'ca bozulması hakkında Daireden çıkan kararı kapsayan 12.07.2005 gün ve E:2005/6819 ve K:2005/8497 sayll ilama karşı karar düzeltilmesi istenilmiş olmakla dosyadaki belgeler okunup gereği konuşulup düşünüldü:

KARAR: Davacı vekili, 19.12.2006 havale tarihli dilekçesi ile Dairemizin 12.07.2005 gün ve E:2005/6819 ve K:2005/8497 sayılı Bozma ilamında yeniden rapor alınması mı gerektiği, yoksa ek rapor alınması yoluna mı gidileceği hususunun belirtilmemesi nedeniyle hükmün tavzih yoluyla düzeltilmesini talep etmiştir. Yukarıda tarih ve sayıları yazılı bozma kararında; alınan raporun değer biçme yöntemi bakımından yasa hükümlerine uygun olduğu belirtilmiş ise de hükme esas alınan bilirkişi raporlarında gerekçesi belirtilmeden emsal taşınmazlar ile dava konusu taşınmaz için Arsa Metrekare Rayiç Bedeli Takdir Komisyonu tarafindan belirlenen emlak vergisine esas olan metrekare değerleri arasındaki oranın tamamen tersine oran kurulmak suretiyle değer biçilmiştir. Bu nedenle, raporlar hüküm kurmaya yeterli olmadığı halde, bu durumun açıklıkla bozma ilamında belirtilmediği anlaşılmakla,

SONUÇ: Davacı vekilinin tavzih talebinin kabulüne, Dairemizin 12.07.2005 tarih ve 2005/6819-8497 sayll kararının 4.bendindeki (Daha değerli olduğu kabul...) kelimelerinden sonra gelmek üzere (Edilmesi nedeniyle alınan raporlar hüküm kurmaya elverişli olmadığından, taraflara emsal göstermeleri için yeniden imkân tanınması, lüzumu halinde resen emsal celbi yoluna gidilmesi ve yeniden inceleme yapılıp gerekçeleri de belirtilmek suretiyle bilirkişi kurullarından ek rapor alınmadan yetersiz bilirkişi raporları esas alınarak hüküm kurulması)bölümünün tavzihen eklenmesine, 4. Bendin sonundaki (Edilerek fazla bedele hükmolunması) bölümünün çıkartılmasına, hükmün geri kalan kısımlarının aynen korunmasına, bu düzeltmenin Dairemizdeki karar asillarına da eklenmesine, 08.02.2007 tarihinde oybirliği ile karar verildi...” (UYAP, 19.05.2018).

\section{SONUÇ}

Kentsel planlama, gelişen kent yapısı, nüfus hareketleri ve ekonomik şartlardan dolayı zaman içerisinde zorunlu hale gelmiştir. Bu bakımından son zamanlarda "kentsel dönüşüm” kavramı çok sık karşımıza çıkmaktadır. Kentsel dönüşüm kavramı, yaygın olarak 1980'li tarihlerden itibaren kentin sağlıksız alanlarının daha sağlıklı ve düzenli bir yaşam alanlarına dönüştürülmesi amacıyla kullanılan araçlardan biri olmuştur. Kentsel dönüşüm süreç bağlamında bakıldığında planlı bir harekettir. Yetkili kuruluşlar tarafından hazırlanan projeler bağlamında bunların onaylanmasıyla kentsel dönüşüm süreci başlamaktadır.

Kentin daha verimli olması için karşımıza çıkan ve değişim ve iyileştirme hareketi olan kentsel dönüşüm, yapıldığı amaca ve yapıldığı yer göre farklı yöntemlerle yapılmaktadır. Bu yöntemler kentsel dönüşüm hareketinin daha hızlı bir şekilde amacı ulaşmasını sağlamaktadır.

Kentsel dönüşüm kavramının alt yapısını yer aldığı kanunlar oluşturmaktadır. Bu kanunlar kapsamında yetkili kuruluşlar belirlenmekte ve uygulanan yerlerin yapısına göre yöntemler belirlenmektedir.

Kentsel dönüşümün mekânsal ve fiziki boyutu var olmakla birlikte, uygulamada sadece fiziki olarak mekânın dönüştürülmesi olarak hayata geçirilmiş, en az mekânsal dönüşüm kadar önemli olan toplumsal ve ekonomik boyutları göz ardı edilmiştir. Oysaki kentsel dönüşüm sadece mekânların dönüştürülmesinden ibaret olmayıp, çöküntüye uğramış veya bozulmuş olan mekânın yeniden biçimlendirilmesinin yanında kentte potansiyel olarak bulunan sosyal ve ekonomik dinamikleri etkileyerek bu yolla bahsedilen çöküntüye uğramış kentsel alanların kente yeniden kazandırılmasını sağlayan uygulamaları ifade etmektedir. Yani sosyal ve ekonomik dinamiklerle kast edilen kentin gelişmesiyle denk ölçüde gelişen sosyal alanlar üniversiteler, hastaneler gibi alanlardır.

Kentsel dönüşüm sürecinde, yapılan projelerin onayı için oldukça fazla zaman kaybı söz konusudur. Yaptığım araştırma ve örneklerden de yola çıkarak bu süreçte projenin uygulamaya geçirileceği alanlarda yaşayanlar mağdur olabilmektedir. Bunların önüne geçebilmek için işlevsel açıdan yetki paylaşımı ya da 
yetki devri yapılarak bu sürecin daha hızlandırılması sağlanabilir. Böylece süreç daha hızlanacak ve bunun yanı sıra o bölgede yaşayanlar mă̆dur olmayacaktır.

Kentsel dönüşüm kavramı, bir kent hareketi olduğu kadar bir hukuki boyutu da içinde barındırmaktadır. Çalışma kapsamında da görüldügü üzere, kentsel dönüşüm sürecinde karşımıza birçok dava örneği çıkmaktadır. Bu davalara idari yargı açısından baktığımızda karşımıza bu kapsamda birçok iptal davası bulunmaktadır. Yapılan literatür taraması sonucunda ulaşılan bilgiler sonucunda tam yargı davalarının, kentsel dönüşüm sürecinde iptal davasına nazaran daha az karşılaşılan örnek olduğu anlaşılmaktadır.

\section{KAYNAKÇA}

Akkar, Müge (2006), "Kentsel Dönüşüm Üzerine Batı'daki Kavramlar, Tanımlar, Süreçler ve Türkiye”, ODTÜ Şehir ve Bölge Planlama Bölümü, Ankara, s.s.29-38.

Akova, Tumar Nur (2010), “Türkiye'de Kentsel Dönüşüm Projeleri Örneği: Altındağ Belediyesi Örneği”, Ankara, s.s.11-12.

Aşık, Rukiye (2007), “Kentsel Dönüşüme Aktörlerin Bakış1: Zeytinburnu Pilot Projesi Örneği”, İstanbul Teknik Üniversitesi Fen Bilimleri Enstitüsü, İstanbul.

Bayram, Ahmet Müfit (2006), "Kentsel Dönüşüm Tartışmaları, Dosya 01 Kentsel Dönüşüm Tartışmaları”, TMMOB Mimarlar Odası Ankara Şubesi Yayını, Ankara, s.s.11-19.

Çakall1, Mehmet Emin (2015), Kentsel Yenilemede Bir Araç Olarak, Kentsel Dönüşüm Projeleri İle İlgili İdari Yargı Kararları, 2.Baskı, Adalet Yayınevi, Ankara.

Erbey, Dilek Erden (2004), “Kentsel Koruma ve Yenileşmede Dönüşüm Projeleri-Eyüp Rehabilitasyon Projeleri”, Şehir ve Bölge Planlama Bölümü, s.s.79-81.

Gözübüyük, Şeref (1996), Yönetsel Yarg1, Turhan Kitabevi, 10.Bask1, Ankara.

İmamoğlu, E. Olcay (1995), “İnsan Evi ve Çevresi, Araştırma Projesi: Sosyal ve Psikolojik Bazı Gözlemler”, Konut Araştırmaları Sempozyumu, Ankara, s.s.357-367.

İnce, Esra Kütük (2006), Kentsel Dönüşümde Yeni Politika, Yasa ve Eğilimlerin Değerlendirilmesi: Kuzey Anakara Girişi Kentsel Dönüşüm Projesi, Yayımlanmamış Yüksek Lisans Tezi, Ankara.

Keleş, Ruşen (1992), Kentleşme Politikası, İmge Yayınevi, Ankara.

Keleş, Ruşen (1998), Kentbilim Terimleri Sözlüğü, İmge Kitabevi Yayınları, Ankara.

Keleş, Ruşen (2004), “Kentsel Dönüşümün Tüzel Alt Yapısı”, Mimar.İst Üç Aylık Mimarlık Kültürü Dergisi, Y11:4, Say1:12, s.s.73-76.

Mirzaoğlu, Yaşar (2017), "İdari Yargılama Usulü Kanunu”.

Özden, Pelin Pınar (2001), "Kentsel Yenileme Uygulamalarında Yerel Yönetimlerin Rolü Üzerine Düşünceler ve İstanbul Örneği”, İstanbul Üniversitesi Siyasal Bilgiler Fakültesi Dergisi, No:23-24, İstanbul, s.s.255-270.

Şahin, S. Zafer (2003), “İmar Planı Değiş̧iklikleri ve İmar Hakları Aracılı̆̆ıyla Yanıltıcı (Pseudo) Kentsel Dönüşüm Senaryoları: Ankara Altındağ İlçesi Örneği”, Kentsel Dönüşüm Sempozyumu Bildiriler Kitabı, Yıldız Teknik Üniversitesi Basım Yayın Merkezi, İstanbul, s.s.89-101.

Yasin, Melikşah (2005), "Kentsel Dönüşüm Uygulamalarının Hukuki Boyutu”, TBB Dergisi, Sayı:60, s.s.105-137.

Yılmaz, Evrim (2009), Türkiye'de Kentsel Dönüşüm Uygulamalarında Süreç ve Faktörler: Sulu Kule 
Örneği, Mimar Sinan Güzel Sanatlar Üniversitesi, Fen Bilimleri Enstitüsü, Yayımlanmamış Yüksek Lisans Tezi.

644 Sayılı Çevre Ve Şehircilik Bakanlığının Teşkilat Ve Görevleri Hakkında Kanun Hükmünde Kararname, R.G.:04.07.2011, Say1:27984.

775 Sayılı Gecekondu Kanunu, R.G.: 30.07.1996, Sayı:12362.

2575 Sayılı Danıştay Kanunu, R.G.:20.01.1982, Sayı:17580.

2577 Sayı1ı İdari Yargılama Usulü Kanunu, R.G.:20.01.1982, Sayı:17580.

2709 Sayılı Türkiye Cumhuriyeti Anayasas1, R.G.:09.11.1982, Say1:17863(Mükerrer).

2942 Sayılı Kamulaştırma Kanunu, R.G.:08.11.1983, Sayı:18215.

2985 Sayıl1 Toplu Konut Kanunu, R.G.: 17.03.1984, Sayı:18344.

5216 Sayılı Büyükşehir Belediyesi Kanunu, R.G.:23.07.2004, Say1:25531.

5226 Sayılı Kültür ve Tabiat Varlıklarını Koruma Kanunu ile Çeşitli Kanunlarda Değişiklik Yapılması Hakkında Kanun, R.G.:14.07.2004.

5302 Sayılı İl Özel İdaresi Kanunu, R.G.:22.02.2005, Sayı:25745.

5366 Sayılı Yıpranan Tarihi ve Kültürel Taşınmaz Varlıkların Yenilenerek Korunması ve Yaşatılarak Kullanılması Hakkında Kanun, R.G.:05.07.2005, Sayı:25866.

5393 Sayıl1 Belediye Kanunu, R.G.:13.07.2005, Sayı:25874.

5543 Sayılı İskan Kanunu, R.G.:26.09.2006, Sayı:26301.

6203 Sayılı Kamulaştırma Kanunu, R.G.:08.11.1983, Sayı:18215.

6306 Sayılı Afet Riski Altındaki Alanların Dönüştürülmesi Hakkındaki Kanun, R.G.:31.05.2012, Say1:28309.

6306 Sayılı Afet Riski Altındaki Alanlarının Dönüştürülmesi Hakkındaki Kanunun Uygulama Yönetmeliği, R.G.:15.12.2012, Say1:28498.

http://www.tdk.gov.tr, Erişim Tarihi:12.05.2018.

http://www.uyap.gov.tr, Erişim Tarihi: 15.05.2018.

http://www.kararlar.uyusmazlik.gov.tr, Erişim Tarihi: 18.05.2018. 